\title{
Production of $\mathrm{Ba}_{2} \mathrm{AINbO}_{6}$ Ceramics and Study of their Stability in Crude Petroleum for the Conservation of Metallic Sensing Elements Used in Petroleum Extraction
}

\author{
Marilaine Moreira de Lima ${ }^{a, *} *$, Rebeka Oliveira Domingues ${ }^{a}$, Ricardo Artur Sanguinetti Ferreira ${ }^{a}$, \\ Yogendra Prasad Yadava \\ ${ }^{a}$ Departamento de Engenharia Mecânica, Universidade Federal de Pernambuco, CEP 50741-530, \\ Recife, PE, Brasil
}

Received: February 22, 2018; Revised: June 11, 2018; Accepted: July 02, 2018

In the present work niobium based complex cubic perovskite oxide $\mathrm{Ba}_{2} \mathrm{AlNbO}_{6}$ ceramics were produced, characterized and their stability in crude petroleum environment was studied for inert ceramic embedding used in petroleum extraction. $\mathrm{Ba}_{2} \mathrm{AlNbO}_{6}$ ceramic powder was prepared by means of thermo-mechanical processing. Structural characteristics of calcined material were investigated by powder $\mathrm{X}$ - ray diffractometry, which presented a single phase complex cubic perovskite structure with lattice parameter $\mathrm{a}=8.3418 \AA$. Compacted $\mathrm{Ba}_{2} \mathrm{AlNbO}_{6}$ ceramics were sintered at $1150^{\circ} \mathrm{C}$ during 72 hours in ambient atmosphere. The microstructure of the sintered ceramics was studied by scanning electron microscopy and mechanical behavior was studied by Vicker's micro-hardness testing. The sintered ceramics were submerged in crude petroleum for 60 days. The ceramics were taken out from petroleum periodically and subjected to structural, microstructural and mechanical characterizations. The results showed that the ceramics submerged in crude petroleum did not suffer any change at any stage of submersion. These characteristics make this material suitable for inert ceramic embedding for sensors used in petroleum extraction.

Keywords: $\mathrm{Ba}_{2} \mathrm{AlNbO} \mathrm{O}_{6}$, production, microstructure, micro-hardness testing, stability in crude petroleum.

\section{Introduction}

Nowadays, there is an increasing demand for sustainable materials and systems to operate in hostile environments such as high temperature or chemically aggressive environments of petroleum extraction industry. In petroleum extraction, different types of sensors are required to monitor temperature, pressure and other vital parameters in the petroleum wells. These sensors work in extremely hostile environment. In case of temperature sensors, normally, sensing elements are metals $\mathrm{Pt}$, $\mathrm{Nb}$ etc., which arehighly sensitive to environmental conditions. Accordingly, these sensors need to be embedded in materials highly inert to petroleum extraction environment. Ceramics are parts of a broad class of materials whose extremely vast characteristics such as, high thermal capacity, resistance to corrosion, fact that they may be insulating, conducting or superconducting, they have magnetic properties or absence of magnetism, and to be hard and resistant but fragile, make them interesting for various technological applications. ${ }^{1-3}$

Study of advanced ceramics makes it possible to develop new technologies, which could be inaccessible with the conventional materials and also to substitute scarce materials. Their cast of production turns to be more viable than those of metals and metallic alloys, as they are lighter materials and stable at higher temperatures. ${ }^{4,5}$ Earlier research works in 1950 and 1960 ' $\mathrm{s}^{6,7}$ identified a large group of ceramics, which have the basic $\mathrm{ABO}_{3}$ perovskite structure or a small distortion of that structure. These complex perovskite oxides generally have the formula $\mathrm{A}_{2} \mathrm{BB}^{\prime} \mathrm{O}_{6}$ or $\mathrm{A}_{3} \mathrm{~B}_{2} \mathrm{~B}^{\prime} \mathrm{O}_{9}$ and result from the ordering of $\mathrm{B}$ and $\mathrm{B}^{\prime}$ cations on the octahedral sites of the basic perovskite unit cell. Due to the increased complexity of the unit cell, a large variety of such materials are possible and hence a more continuous progression of lattice parameter could be produced. ${ }^{7-12}$ Due to high stability in hostile environment, many of the new technologies incorporate perovskite structure based ceramics in their manufacture activities for such applications. We are working on fabrication of ceramic encapsulated temperature sensor for petroleum extraction industry ${ }^{13-15}$ and in the present work we have developed and produced niobium based complex cubic perovskite oxide $\mathrm{Ba}_{2} \mathrm{AlNbO}_{6}$ ceramics and studied their stability in crude petroleum environment for the fabrication 
of inert ceramic embedding for temperature sensors used in petroleum extraction.

\section{Experimental Details}

$\mathrm{Ba}_{2} \mathrm{AlNbO}_{6}$ ceramic powder was prepared through thermomechanical solid-state processing route. Stoichiometric ratios of high purity (99.99\%) constituent oxides $\mathrm{BaCO}_{3}, \mathrm{Al}_{2} \mathrm{O}_{3}$, and $\mathrm{Nb}_{2} \mathrm{O}_{5}$ were mixed and homogenized by means of a high energy ball mill using steel cylinder and alumina balls. Homogenized mixture was compacted as circular discs of 30 $\mathrm{mm}$ diameter with a thickness of about $4-5 \mathrm{~mm}$. Uniaxial powder compaction was carried out in a hydraulic press and hard steel mould made of abrasion resistant AISI A2 steel (HRC 58) at a pressure of $4 \mathrm{ton} / \mathrm{cm}^{2}$. The compacted discs were calcined in a high temperature muffle furnace (Muffle Furnace Jung model 0614) at a temperature of $1150^{\circ} \mathrm{C}$ for 48 hours in ambient atmosphere. After calcination, samples were furnace cooled to room temperature. The calcined material was subjected to X-ray powder diffraction (XRD) analysis for structural characterization and phase identification studies. X-ray diffraction patterns were recorded by using a Shimadzu, X-ray powder diffractometry, equipped with $\mathrm{Cu}-\mathrm{K}_{\alpha}$ radiation $(\lambda=1.5406 \AA)$. After the structural analysis and identification of $\mathrm{Ba}_{2} \mathrm{AlNbO}_{6}$ phase formation, calcined $\mathrm{Ba}_{2} \mathrm{AlNbO}_{6}$ material were again subjected to grinding in high energy ball for 24 hours ${ }^{16,17}$ for ceramic fine powder production and homogenization of particle size distribution.

For the fabrication of ceramic components and sintering of $\mathrm{Ba}_{2} \mathrm{AlNbO}_{6}$ ceramics, circular discs of $15 \mathrm{~mm}$ diameter and $3 \mathrm{~mm}$ thickness were produced by uniaxial pressing technique using the same above referred mould and a hydraulic press at a pressure load of $12 \mathrm{ton} / \mathrm{cm}^{2}$. For better compression, each fraction of pressure was applied for 5 minutes to stabilize the pressure load distribution in the compact and homogenize the necessary pressure load. The compressed ceramic discs were subjected to normal solid state sintering process at a temperature of $1150^{\circ} \mathrm{C}$ for 72 hours in ambient atmosphere, using the same above referred high temperature muffle furnace and finally furnace cooled to room temperature. As sintering is a thermo-dynamic process and due to furnace temperature limitation, it was necessary to increase the sintering time to achieve the sintered body. ${ }^{17}$

Microstructural analysis of the sintered $\mathrm{Ba}_{2} \mathrm{AlNbO}_{6}$ ceramics was carried out by scanning electron microscopy (model HITACHI TM3000), using backscattered electrons. To observe the microstructure, the samples were placed in a metal coating device to receive a 9 micronthin layer of gold, since they are not electrically conducting, to get SEM images. Mechanical properties of the sintered ceramics were studied through Vicker's micro-hardness testing. For the indentation in Vicker's micro-hardness tester, the samples were polished with \# 360, \# 400, \# 600, \# 1200, \# 1500 grade sand papers, followed by mechanical polishing using diamond paste with
1 micron particle size. For this testing a Vicker's hardness indentor model HVS-5 No 0021 was used. The Vickers micro - hardness (MHV) is given by equation. ${ }^{18}$

$$
M H V=1.8544 P / d^{2}
$$

Were $P$ is the load and $d$ is the average diagonal of the square indentation produced by the pyramidal indentor in the sample.

For the study of stability of $\mathrm{Ba}_{2} \mathrm{AlNbO}_{6}$ ceramics in petroleum extraction environment, the sintered ceramics were submerged in crude petroleum for 60 days. Crude petroleum for this study, extracted from the earthen and offshore petroleum wells of the North-east region of Brazil, was provided by PETROBRAS, Brazil. The $\mathrm{Ba}_{2} \mathrm{AlNbO}_{6}$ ceramics were periodically taken out from the petroleum reservoir every 15 days and subjected to X-ray diffractometry, optical microscopy and Vicker's micro-hardness testing to observe if there were any changes in their structural and mechanical characteristics due to crude petroleum environment.

\section{Results and Discussion}

The XRD spectrum of a typical $\mathrm{Ba}_{2} \mathrm{AlNbO}_{6}$ ceramics produced in this work is shown in Fig. 1. It consists of strong peaks characteristics of primitive cubic perovskite structure plus few weak reflection lines arising from the superlattice reflections. No evidence for a distortion from the cubic symmetry is observed in the XRD spectrum. The basic perovskite composition is $\mathrm{ABO}_{3}$, where $\mathrm{A}$ is a large ion suitable to the 12-coordinated cube-octahedral sites and $\mathrm{B}$ is a smaller ion suitable to the 6-coordinated octahedral site. Complex perovskite with mixed species on a site (particularly the $\mathrm{B}$ site) may be represented by multiples of this formula unit and a larger unit cell, e.g. $\mathrm{A}_{2} \mathrm{BB}^{\prime} \mathrm{O}_{6}, \mathrm{~A}_{3} \mathrm{~B}_{2} \mathrm{~B}^{\prime} \mathrm{O}_{9}$ etc. ${ }^{21-23}$ Thus, in $\mathrm{Ba}_{2} \mathrm{AlNbO}_{6}$ composition, $\mathrm{Ba}^{2+}$, with largest ionic radius $\left(1.35 \AA\right.$ ) occupies position $\mathrm{A}, \mathrm{Al}^{3+}$ (ionic radius 0.55 $\AA$ ) and $\mathrm{Nb}^{5+}$ (ionic radius $0.70 \AA$ ) cations occupy B and B' positions on the $\mathrm{B}$ site due to their smaller ionic radii compared

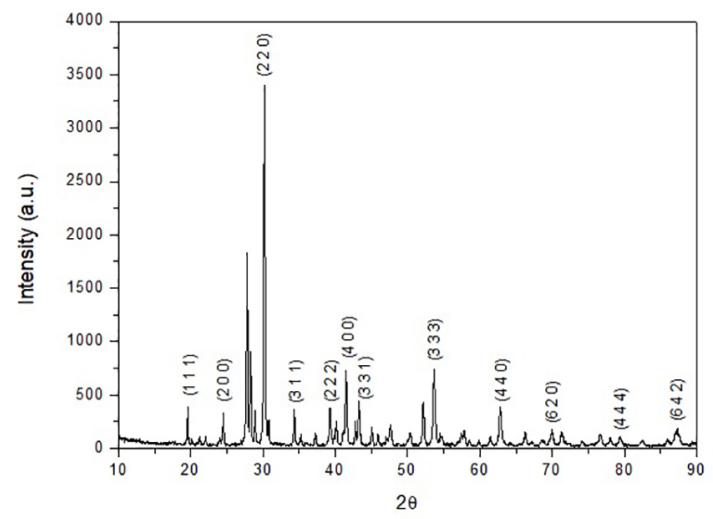

Figure 1. X- ray diffraction pattern of $\mathrm{Ba}_{2} \mathrm{AlNbO}_{6}$ ceramics 
to that of $\mathrm{Ba}^{2+}$ cation. Due to the ordering of $\mathrm{B}$ and $\mathrm{B}^{\prime}$ on octahedral site of the $\mathrm{ABO}_{3}$ unit cell there is a doubling in the lattice parameter of the basic cubic perovskite unit cell. Thus, the whole XRD pattern of $\mathrm{Ba}_{2} \mathrm{AlNbO}_{6}$ can be indexed in a $\mathrm{A}_{2} \mathrm{BB}^{\prime} \mathrm{O}_{6}$ cubic cell with the cell edge $\mathrm{a}=2 \mathrm{a}_{\mathrm{p}}$ where $\mathrm{a}_{\mathrm{p}}$ is the cell lattice of the cubic perovskite. The XRD spectrum of $\mathrm{Ba}_{2} \mathrm{AlNbO}_{6}$ is similar to $\mathrm{A}_{2} \mathrm{BB}^{\prime} \mathrm{O}_{6}$ type complex cubic perovskite oxides e.g. $\mathrm{Ba}_{2} \mathrm{YNbO}_{6}, \mathrm{Ba}_{2} \mathrm{ErSbO}_{6}, \mathrm{Ba}_{2} \mathrm{DyNbO}_{6}$ etc. reported in the ICDD files, as judged by the similarity in d-spacings and intensity ratios. Experimental XRD data of $\mathrm{Ba}_{2} \mathrm{AlNbO}_{6}$ ceramics is presented in Table 1 .

Presence of the superstructure reflection lines (111) and (333) in the XRD spectrum of $\mathrm{Ba}_{2} \mathrm{AlNbO}_{6}$ is the signature of an ordered complex cubic perovskite structure. In a substitutional solid solution $\mathrm{BB}^{\prime}$, there is a random arrangement of $\mathrm{B}$ and $\mathrm{B}^{\prime}$ on equivalent lattice positions in the crystal structure. Upon suitable heat treatment, the random solid solution rearranges into a structure in which $\mathrm{B}$ and $\mathrm{B}$ ' occupy the same set of positions but in a regular way, such a structure is described as superstructure. In the superstructure, the positions occupied by B and B' are no longer equivalent and this feature is exhibited in the XRD spectrum of the material by the presence of superstructure reflection lines. ${ }^{19,20}$

For double cubic perovskite of the formula $\mathrm{A}_{2} \mathrm{BB}^{\prime} \mathrm{O}_{6}$ the intensity, in particular of the (111) and/or (311) superstructure reflection, is proportional to the difference in scattering power of the $\mathrm{B}$ and $\mathrm{B}^{\prime}$ atoms, when all the atoms are situated in the ideal position. A disordered arrangement of $\mathrm{B}$ and $\mathrm{B}^{\prime}$ should result in zero intensity. Therefore $\mathrm{Al}^{3+}$ and $\mathrm{Nb}^{5+}$ cation ordering in $\mathrm{Ba}_{2} \mathrm{AlNbO}_{6}$ in $\mathrm{B}$ and $\mathrm{B}^{\prime}$ positions is clearly distinguished by the presence of the significant intensity of (111) and (333) superstructural reflection lines. Based on above discussion we have now indexed the XRD peaks of $\mathrm{Ba}_{2} \mathrm{AlNbO}_{6}$ as an ordered complex cubic perovskite with $\mathrm{A}_{2} \mathrm{BB}^{\prime} \mathrm{O}_{6}$ crystal structure. The lattice parameter of $\mathrm{Ba}_{2} \mathrm{AlNbO}_{6}$, calculated from the experimental XRD data, is $\mathrm{a}_{\exp }=8.3418 \AA$.

Table. $1 \mathrm{XRD}$ data of $\mathrm{Ba}_{2} \mathrm{AlNbO}_{6}$.

\begin{tabular}{lccc}
\hline S. N. & $2 \theta$ & $\mathrm{d}(\AA)$ & $\mathrm{h} \mathrm{k} 1$ \\
\hline 1 & 19.62 & 4.5367 & 111 \\
2 & 24.52 & 3.6402 & 200 \\
3 & 30.20 & 2.9673 & 220 \\
4 & 34.32 & 2.6200 & 311 \\
5 & 39.28 & 2.3000 & 222 \\
6 & 41.48 & 2.1828 & 400 \\
7 & 43.28 & 2.0961 & 331 \\
8 & 53.66 & 1.7127 & 333 \\
9 & 62.80 & 1.4837 & 440 \\
10 & 69.98 & 1.3480 & 620 \\
11 & 79.38 & 1.2104 & 444 \\
12 & 87.30 & 1.1199 & 642 \\
\hline
\end{tabular}

For the $\mathrm{A}_{2} \mathrm{BB}^{\prime} \mathrm{O}_{6}$ type complex cubic perovskite oxides, theoretical value of the unit cell parameter can be calculated using following Shannon and Prewit mode ${ }^{21}$ :

$$
\begin{gathered}
a_{A}=\frac{2\left(R_{A}+R_{0}\right)}{\sqrt{2}} \\
a_{B}=R_{B}+R_{B^{\prime}}+2 R_{0} \\
a_{c a l}=\frac{\left(a_{A}+a_{B}\right)}{2}
\end{gathered}
$$

Where, $R_{A}, R_{B}, R_{B^{\prime}}$ and $R_{O}$ are ionic radius of $A, B, B^{\prime}$ cations and oxygen, respectively. Using these equations theoretical value of unit cell parameter of $\mathrm{Ba}_{2} \mathrm{AlNbO}_{6}$ is $\mathrm{a}_{\text {cal }}=7.9991 \AA$. Experimental value of unit cell parameter of $\mathrm{Ba}_{2} \mathrm{AlNbO}_{6}\left(\mathrm{a}_{\text {exp }}=8.3418 \AA\right)$ is $4.39 \%$ higher than its theoretical value $\left(\mathrm{a}_{\text {cal }}=7.9991 \AA\right)$, which can be justified because Shannon and Prewit mode ${ }^{24}$ is based on hard-sphere model approximation.

As stated earlier, the objective of this work is to produce $\mathrm{Ba}_{2} \mathrm{AlNbO}_{6}$ ceramics with good mechanical strength in order to guarantee the required qualities that a final ceramic product must have for structural applications. Production and functional ability of polycrystalline ceramic products are highly dependent on their microstructural features, which in turn are highly influenced by sintering kinetics. Sintering process uses the heat and mechanisms of material transport to convert after ceramic into dense polycrystalline solids. The driving force in the sintering process is obtained by the reduction of the total surface energy, which increases the contact and growth between the grains. The smaller grains are transformed into the bigger grains and, consequently, the pores substituted by the solid materials. The necessity to get uniformity in the microstructure is for preventing the creation of tensions that make to appear (or they magnify) empty spaces, for being concentrative of tensions, assist in the propagation of cracks and micro-cracks in the sintered body. Microstructural features define the final product quality of the ceramic products and their mechanical strength.

Microstructural features of $\mathrm{Ba}_{2} \mathrm{AlNbO}_{6}$ ceramics sintered at $1150^{\circ} \mathrm{C}$ temperatures for 72 hours, was studied by scanning electron microscopy and Fig. 2 presents typical microstructures of these ceramics. As seen from these figures, sintering temperature has a significant role in sintering behavior of these ceramics. $\mathrm{Ba}_{2} \mathrm{AlNbO}_{6}$ ceramics sintered at $1150^{\circ} \mathrm{C}$ presented good microstructures with uniform surface morphology, grain homogeneity and particle size distribution.

Mechanical properties of $\mathrm{Ba}_{2} \mathrm{AlNbO}_{6}$ ceramics sintered at $1150^{\circ} \mathrm{C}$ were evaluated by Vicker's microhardness tests. These tests were performed on 15 polished discs of $\mathrm{Ba}_{2} \mathrm{AlNbO}_{6}$ ceramics with 10 indentation on each discs to obtain the arithmetic mean value of $(56.43 \pm 4.45) \mathrm{KgF} / \mathrm{mm}^{2}$. 


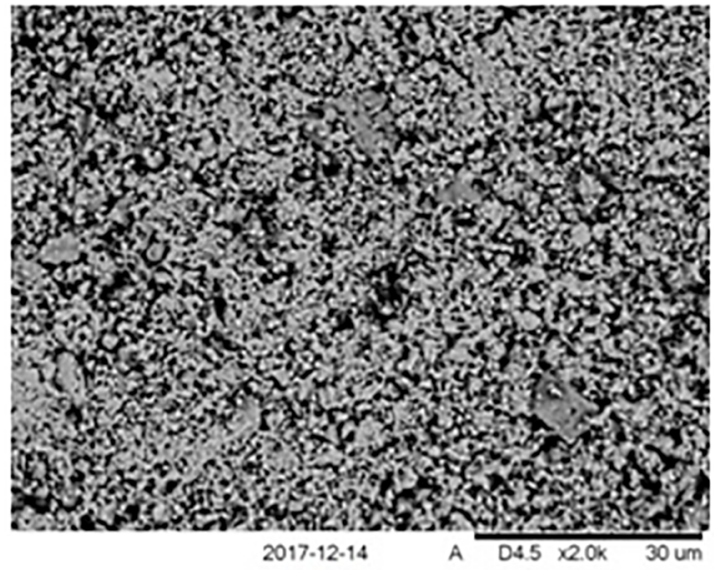

DEMECICTG

(A)

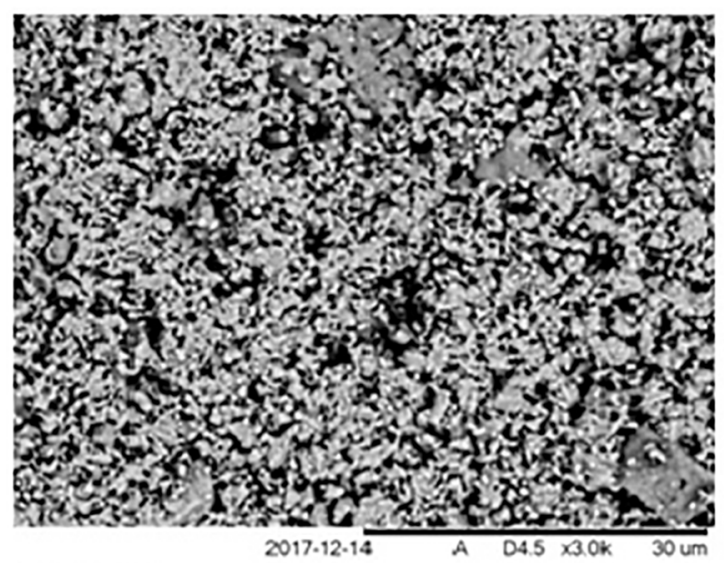

DEMECICTG

(B)

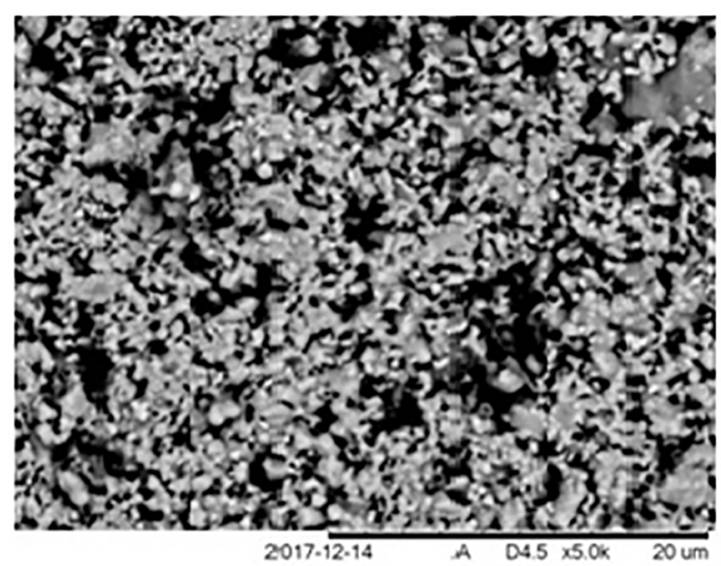

DEMEC ICTG

(C)

Figure 2. SEM micrographs of $\mathrm{Ba}_{2} \mathrm{AlNbO}_{6}$ ceramics sintered at 1150 ${ }^{\circ} \mathrm{C}$ with magnification of: (A) 2,000X (B) 3,000X and (C) 5,000X
For the study of stability of these ceramics in petroleum extraction environment, we used $\mathrm{Ba}_{2} \mathrm{AlNbO}_{6}$ discs sintered at $1150^{\circ} \mathrm{C}$ as these discs presented good microstructural features and mechanical hardness. These discs were firstly polished like mirror surface and subjected to optical microscopy. After observation in optical microscopy these discs were partitioned in two equal parts, using diamond disc cutter, to be submersed each one part in the crude petroleum extracted from earthen and offshore petroleum wells, respectively. This was carried out purposely to ensure that ceramics submersed in crude petroleum extracted from earthen and offshore petroleum wells have the same microstructure and mechanical hardness. The ceramics were submerged in crude petroleum for 60 days. The ceramics were taken out from the petroleum reservoir periodically, every 15 days and tested to observe if there are any changes in their structural, microstructural and mechanical characteristics due to crude petroleum environment.

The XRD spectra of $\mathrm{Ba}_{2} \mathrm{AlNbO}_{6}$ ceramics before submersion in crude petroleum, as seen from Fig. 3, along with typical results of X-ray diffractometry carried out on $\mathrm{Ba}_{2} \mathrm{AlNbO}_{6}$ ceramics after 60 days of submersion in earthen and offshore crude petroleum are shown in Fig. 4 both the XRD spectrum of $\mathrm{Ba}_{2} \mathrm{AlNbO}_{6}$ ceramics submersed in
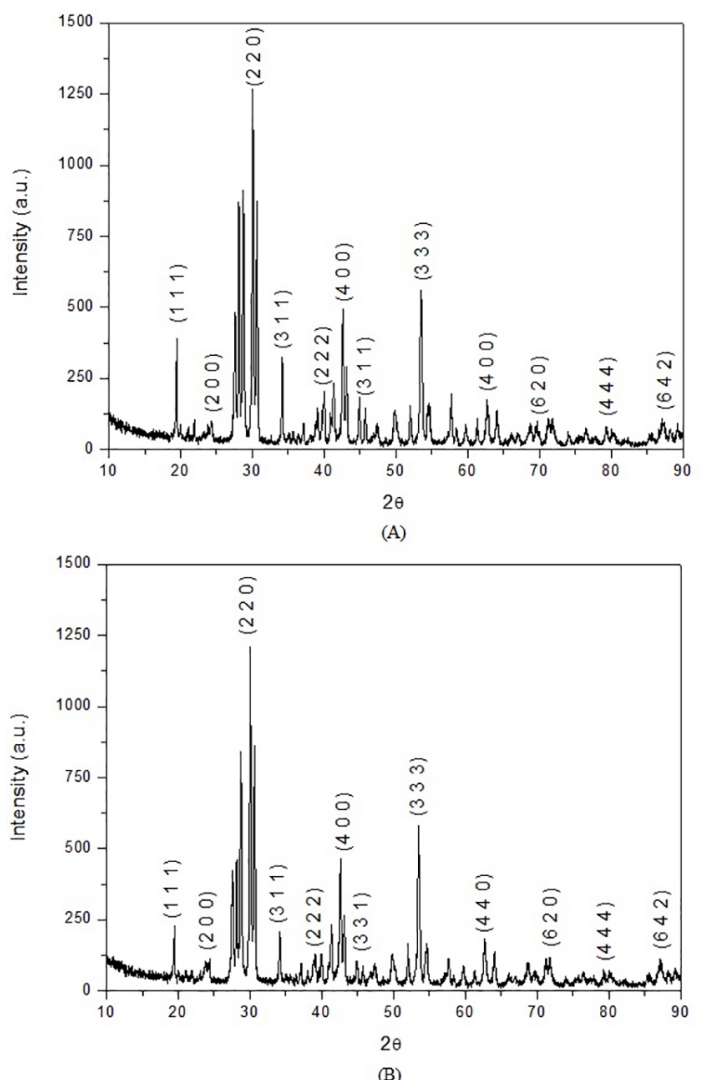

Figure 3. X- ray diffraction patterns of $\mathrm{Ba}_{2} \mathrm{AlNbO}_{6}$ ceramics: (A) after 60 days submersion in earthen crude petroleum and (B) after 60 days submersion in offshore crude petroleum 


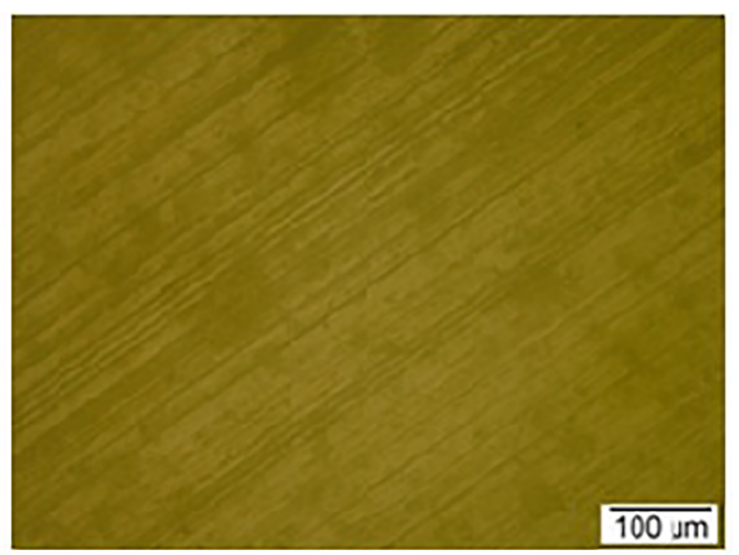

(A)
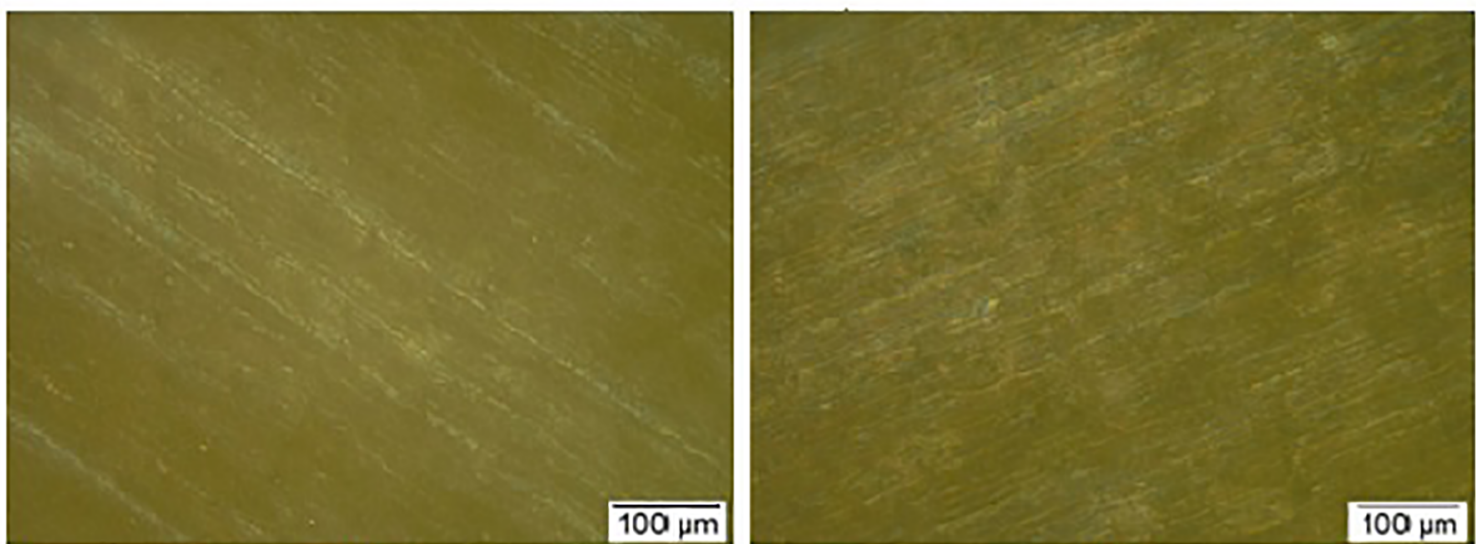

(B)

(C)
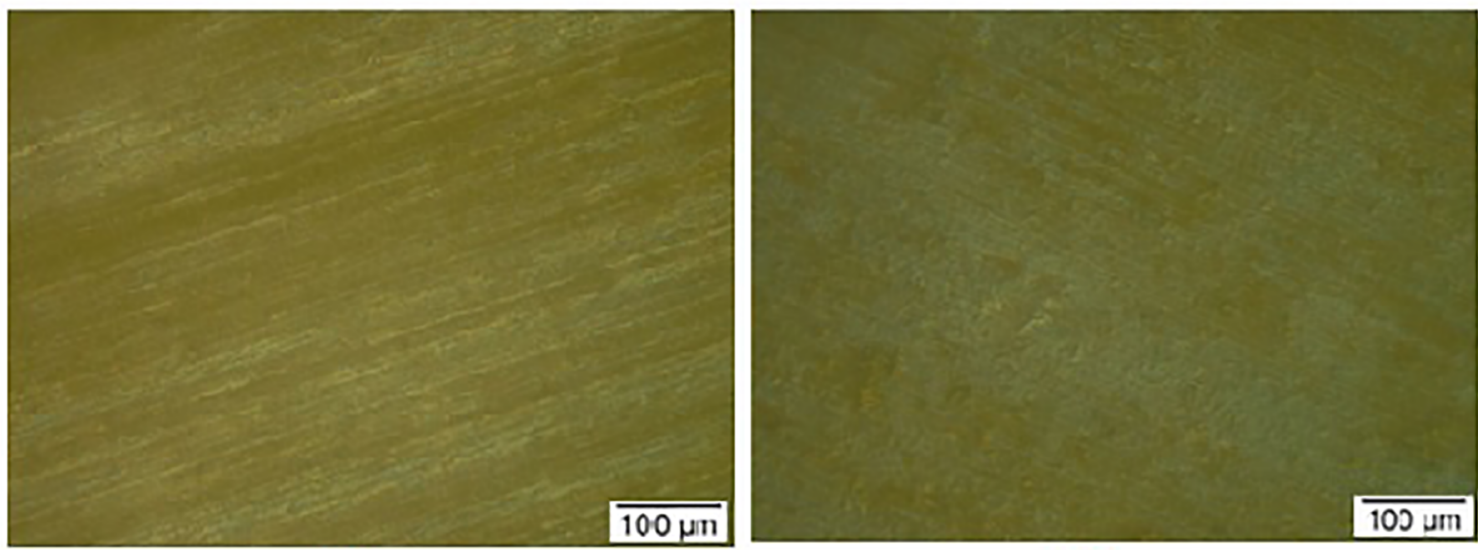

(D)

(E)

Figure 4. Optical micrograph (200X) of $\mathrm{Ba}_{2} \mathrm{AlNbO}_{6}$ ceramics before and after submersion in crude petroleum: (A) Before submersion in crude petroleum, (B and C) after 45 and 60 days submersion, respectively, in earthen crude petroleum and (D and E) after 45 and 60 days submersion, respectively, in offshore crude petroleum 
earthen and offshore petroleum present the (111) and (333) peaks characteristics of complex perovskite oxides as the XRD spectrum of $\mathrm{Ba}_{2} \mathrm{AlNbO}_{6}$ ceramics before submersion in crude petroleum.

Typical Vicker's microhardness tests results carried out on $\mathrm{Ba}_{2} \mathrm{AlNbO}_{6}$ ceramics before and after 60 days of submersion in crude petroleum are presented in Table 2. As we can see from these results $\mathrm{Ba}_{2} \mathrm{AlNbO}_{6}$ ceramics increased their mechanical hardness due to crude petroleum environment.

Microstructural analysis of $\mathrm{Ba}_{2} \mathrm{AlNbO}_{6}$ ceramics after submersion in crude petroleum was carried out using optical microscopy since after submersion in crude petroleum it was extremely difficult to use scanning electron microscopy due to the vacuum requirements. Fig. 4 presents the optical micrographs of $\mathrm{Ba}_{2} \mathrm{AlNbO}_{6}$ ceramics before and after submersion in crude petroleum for 45 and 60 days respectively. As seen from Fig.4 microstructural features of $\mathrm{Ba}_{2} \mathrm{AlNbO}_{6}$ ceramics remain identical before and after submersion in crude petroleum without degradation in microstructural features due to crude petroleum environment.

From these promising results we conclude that $\mathrm{Ba}_{2} \mathrm{AlNbO}_{6}$ ceramics are stable in the aggressive crude petroleum environment and thus could be potential candidate ceramic encapsulation in the fabrication of temperature sensors for temperature monitoring in petroleum wells. ${ }^{17,22,23,24}$

Table 2. Vicker's microharness of $\mathrm{Ba}_{2} \mathrm{AlNbO}_{6}$ ceramics before and after submersion in crude petroleum for 60 days.

\begin{tabular}{|c|c|c|}
\hline Ceramics & $\begin{array}{c}\mathrm{MHV} \\
\left(\mathrm{KgF} / \mathrm{mm}^{2}\right)\end{array}$ & $\begin{array}{l}\text { Standard } \\
\text { deviation }\end{array}$ \\
\hline $\begin{array}{l}\mathrm{Ba}_{2} \mathrm{AlNbO}_{6} \text { ceramics before } \\
\text { submersion in crude petroleum }\end{array}$ & 56.43 & 4.45 \\
\hline $\begin{array}{l}\mathrm{Ba}_{2} \mathrm{AlNbO}_{6} \text { ceramics after } 60 \text { days } \\
\text { submersion in earthen crude } \\
\text { petroleum }\end{array}$ & 70.49 & 4.93 \\
\hline $\begin{array}{l}\mathrm{Ba}_{2} \mathrm{AlNbO}_{6} \text { ceramics after } 60 \text { days } \\
\text { submersion in offshore crude } \\
\text { petroleum }\end{array}$ & 69.81 & 4.41 \\
\hline
\end{tabular}

\section{Conclusions}

In the present work we have produced a niobium based complex cubic perovskite oxide $\mathrm{Ba}_{2} \mathrm{AlNbO}_{6}$ ceramics and studied their stability in crude petroleum environment for the manufacture of inertceramic embedding for temperature sensors used in petroleum extraction. $\mathrm{Ba}_{2} \mathrm{AlNbO}_{6}$ ceramic powder was prepared through thermo-mechanical solidstate processing route. Structural characteristics and phase identification of calcined material was investigated by powder $\mathrm{X}$ - ray diffractometry, which presented a single phase complex cubic perovskite structure with lattice parameter a $=8.3418 \AA$. The microstructure of the $\mathrm{Ba}_{2} \mathrm{AlNbO}_{6}$ ceramics sintered at $1150^{\circ} \mathrm{C}$ presented a homogenous morphology and particle size distribution. The mechanical behaviour of the sintered ceramics was studied by Vicker's micro-hardness testing, which gave a reasonablevalue of $\mathrm{MHV}=56,43 \mathrm{KgF} /$ $\mathrm{mm}^{2}$ for ceramics sintered at $1150^{\circ} \mathrm{C}$, which is satisfactory for encapsulation application of these ceramics. Results of X-ray diffractometry, microstructural and mechanical tests showed that $\mathrm{Ba}_{2} \mathrm{AlNbO}_{6}$ ceramics submerged in crude petroleum did not suffer change at any stage of submersion. From these results we conclude that $\mathrm{Ba}_{2} \mathrm{AlNbO}_{6}$ ceramics are stable in the aggressive crude petroleum environment and thus could be potential candidate ceramic encapsulation in the fabrication of temperature sensors for temperature monitoring in petroleum wells.

\section{Acknowledgments}

The authors acknowledge CAPES and CNPq for the financial support for this research project.

\section{References}

1. Chandler M. Ceramics in the Modern World. New York: Doubleday; 1967.

2. Reed JS. Principles of Ceramic Processing. Hoboken: John Wiley and Sons; 1988.

3. Richerson DW. Modern Ceramic Engineering: Properties, Processing, and Use in Design. New York: Marcel Dekker; 1982.

4. TejucaLG, Fierro JLG, eds. Properties and Applications of Perovskite-Type Oxides. New York: Marcel Dekker; 1993.

5. M. H. Lewis. Engineering Ceramics: Twentieth Century Developments and Prospects for the New Millennium. Proceedings of International Symposium on Materials for the Third Millennium, Kanpur, 2001, pp. 47-73.

6. Galasso F, Katz L, Ward R. Substitution in TheOctahedrally Coördinated Cation Positions in Compounds of the Perovskite Type1,2. Journal of the American Chemical Society. 1959;81(4):820823.

7. Galaso F, Barrante JR, Katz L. Alkaline Earth-Tantalum-Oxygen Phases Including the Crystal Structure of an Ordered Perovskite Compound, $\mathrm{Ba}_{3} \mathrm{SrTa}_{2} \mathrm{O}_{9}$. Journal of the American Chemical Society. 1961;83(3):2830-2832.

8. BrandleCD, Fratello VJ. Preparation of perovskite oxides for high Tc superconductor substrates. Journal of Materials Research. 1990;5(10):2160-2164.

9. Fratello VJ, Berkstresser CW, BrandleCD, Ven Graitis AJ. Nickel containing Perovskites. Journal of Crystal Growth. 1996;166(1-4):878-882.

10. Hove JE, Riley WC. Modern Ceramics. New York: John Wiley and Sons; 1965.

11. Lapa CM. Produção e desenvolvimento de cerâmicas tungstatoperovskitas complexas para componentes cerâmicos de sensores de temperatura de poços de petróleo. [Dissertation]. Recife: Federal University of Pernambuco; 2004. 
12. Istomin SY, SvenssonG, Kohler J. Structures and Properties of the Perovskite-Type Compounds $\mathrm{Na}_{1-\mathrm{x}} \mathrm{Sr}_{\mathrm{x}} \mathrm{NbO}_{3}(0.1=\mathrm{x}=0.9)$ From Insulating to Metallic Conductivity. Journal of Solid State Chemistry. 2002;167(1):7-16.

13. Lapa CM, Ferreira RAS, Aguiar JA, Silva CL, Souza DPF, Yadava YP. Sintering, Microstructure and Mechanical Properties of $\mathrm{Ba}_{2} \mathrm{HoWO}_{5.5}$ Ceramics. Materials Science Forum. 2005;498499:529-534.

14. Yadava YP, Ferreira RAS. Study of Sintering Behaviorof $\mathrm{Ba}_{2} \mathrm{AlSnO}_{55}$ Ceramic Powder Compacts as Substrate for Temperature Sensing Devices. Materials Science Forum. 2008;591-593:661-666.

15. Yadava YP, Ferreira RAS. High Density $\mathrm{Ba}_{2} \mathrm{AlWO}_{5.5}$ Ceramic Compacts Produced through Liquid Phase Sintering Route for Temperature Sensores. Materials Science Forum. 2008;591593:448-453.

16. RibeiroMJPM, Abrantes JCC. Moagem em Moinho de Bolas: Estudo de Algumas Variáveis de Processo. Kéramica.2015;245:15-20.

17. Yadava YP, Lima MM, Oliveira JCS, Ferreira RAS. Production of $\mathrm{Ca}_{2} \mathrm{AlNbO}_{6}$ Ceramics and Study of their Stability in Crude Petroleum for the Conservation of Metallic Sensing Elements Used in Petroleum Extraction. Materials Sciences and Applications. 2012;3(6):408-413.
18. IostA, Bigot R. Identation size effect: reality or artefact? Journal of Materials Science. 1996;31(13):3573-3577.

19. Koshy J, Kumar KS, Kurian J, Yadava YP, Damodaran AD. Rare-earth Barium Stannates Synthesis, Characterization and Potentialuse as Substrate for $\mathrm{YBa}_{2} \mathrm{Cu}_{3} \mathrm{O}_{7}$ Superconductor. Journal of the American Chemical Society. 1995;78(11):30883092.

20. Jha P, Ganguli AK. Complex rare-earth titanates with the perovskite structure: Rietveld studies and dielectric properties. Solid State Sciences. 2004;6(7):663-671.

21. Shannon RD, Prewit CT. Effective Ionic Radii in Oxides and Fluorides. Acta Crystallographica B. 1969;25:925-946.

22. Oliveira JCS, Ferreira RAS, Yadava YP. Sintering of $\mathrm{Ca}_{2} \mathrm{MgWO}_{6}$ Ceramic and its Stability Test in Crude Petroleum. Materials Science Forum. 2015;820:149-154.

23. Oliveira JCS, Ferreira RAS, Yadava YP. Sintering $\mathrm{Sr}_{2} \mathrm{MgWO}_{6}$ Ceramic and their Reactivity to Petroleum. 2014;798-799:154-159.

24. Oliveira JCS, Ferreira RAS, Yadava YP. Production, Sintering and Mechanical Properties of $\mathrm{Ca}_{2} \mathrm{MgWO}_{6}$, a New Complex Cubic Perovskite Ceramic. Materials Science Forum. 2012;727728:731-735. 